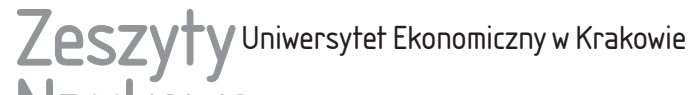 Naukowe
}

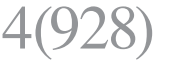

ISSN 1898-6447

Zesz. Nauk. UEK, 2014; 4 (928): 35-50 DOI: 10.15678/ZNUEK.2014.0928.0403

\author{
Monika Musiat-Malagó \\ Katedra Gospodarki Regionalnej \\ Uniwersytet Ekonomiczny w Krakowie
}

\section{Zróżnicowanie dostępności transportowej województw Polski}

\section{Streszczenie}

Obecny stopień rozwoju i stan techniczny infrastruktury transportu w Polsce stał się jedną z podstawowych barier wzrostu gospodarczego i modernizacji kraju, które hamują proces pełnej integracji Polski z Unią Europejską w obszarze polityki transportowej. W wyniku niedorozwoju infrastruktury transportowej pogorszeniu uległa dostępność przestrzenna wielu ośrodków i regionów w skali regionalnej, krajowej i europejskiej.

Badania dostępności transportowej zostały przeprowadzone metodami taksonomicznymi z wykorzystaniem danych na koniec 2012 r. Celem przeprowadzonego badania jest dokonanie oceny zróżnicowania dostępności transportowej polskich regionów z wykorzystaniem miar syntetycznych umożliwiających ich uszeregowanie i pogrupowanie.

Słowa kluczowe: infrastruktura transportowa, dostępność przestrzenna, dostępność transportowa, sieć drogowa, sieć kolejowa.

\section{Wprowadzenie}

Dostępność transportowa jest jednym z podstawowych pojęć z zakresu badań rozwoju transportu $\mathrm{W}$ aspekcie przestrzennym. W literaturze przedmiotu pojęcie dostępności transportowej nie jest jednoznaczne. Jest ono używane w różnych kontekstach, m.in. w odniesieniu do systemu transportowego, różnego rodzaju usług, ponadto jest czynnikiem rozwoju gospodarczego regionów, a także czynnikiem wpływającym na ich atrakcyjność inwestycyjną. 
Celem artykułu jest ocena zróżnicowania dostępności transportowej regionów Polski. Badania przeprowadzono na poziomie województw z wykorzystaniem miar syntetycznych.

\section{Diagnoza aktualnej sytuacji w obszarze polskiej infrastruktury transportowej}

Efektywny i sprawny system transportowy jest istotnym czynnikiem rozwoju regionów. W rozwoju infrastruktury poszczególnych gałęzi transportu w Polsce występują znaczne dysproporcje. Niskie nakłady $\mathrm{i}$ inne błędy popełnione w procesie rozwoju transportu spowodowały, że infrastruktura jego gałęzi, najbardziej nawet rozwiniętych, nie odpowiada standardom europejskim. W wyniku niedorozwoju infrastruktury transportowej wykształciły się w Polsce strefy o niskiej dostępności przestrzennej w systemie regionalnym, krajowym i europejskim.

W 2012 r. Polska posiadała sieć dróg publicznych o łącznej długości $412035,1 \mathrm{~km}$, tj. zaledwie o 10,5\% więcej niż w 2000 r., w tym ogólna długość dróg krajowych wyniosła $19182,1 \mathrm{~km}$. Drogi o nawierzchni twardej o długości $280719,1 \mathrm{~km}$ stanowiły 68,1\% długości dróg publicznych, z czego 91,9\% miało nawierzchnię ulepszoną.

Polska sieć drogowa charakteryzuje się relatywnie wysoką gęstością szlaków o nawierzchni twardej, w miarę proporcjonalną do gęstości zaludnienia. Średnio w kraju na $100 \mathrm{~km}^{2}$ przypadało $89,8 \mathrm{~km}$ dróg o nawierzchni twardej, zaś na 10 tys. mieszkańców - 72,9 km. Najwyższe wskaźniki gęstości sieci drogowej odnotowano w województwie śląskim $(173,2)$, a następnie w małopolskim $(159,2)$, świętokrzyskim $(116,2)$ i łódzkim $(105,3)$, najniższe zaś w województwach warmińsko-mazurskim $(53,3)$, lubuskim $(59,5)$ i zachodniopomorskim $(59,6)$. Z kolei najwyższy wskaźnik gęstości sieci drogowej w stosunku do zaludnienia miały województwa świętokrzyskie $(106,8)$ i podlaskie $(103,4)$ natomiast najniższy śląskie $(46,3)$ i pomorskie $(54,9)$.

Najkorzystniejszy współczynnik średnioważony ${ }^{1}$ posiadało województwo świętokrzyskie $(111,4)$, zaś najniższą gęstość przestrzenną sieci dróg w przeliczeniu na jednego mieszkańca miało województwo pomorskie $(61,4)$ - tabela 1.

Ważną częścią systemu dróg są autostrady i drogi ekspresowe. W 2012 r. długość autostrad i dróg ekspresowych wynosiła odpowiednio 1365,0 i 1052,4km. Pomimo że długość dróg o podwyższonym standardzie w Polsce systematycznie rośnie (długość autostrad i dróg ekspresowych znacznie wzrosła od 2000 r. o 1007 i 859 km, czyli odpowiednio o 73\% i 82\%), to nadal ich udział w ogólnej

\footnotetext{
${ }^{1}$ Wskaźnik średnioważony - długość sieci drogowej podzielona przez pierwiastek kwadratowy z iloczynu liczby mieszkańców i powierzchni województwa.
} 


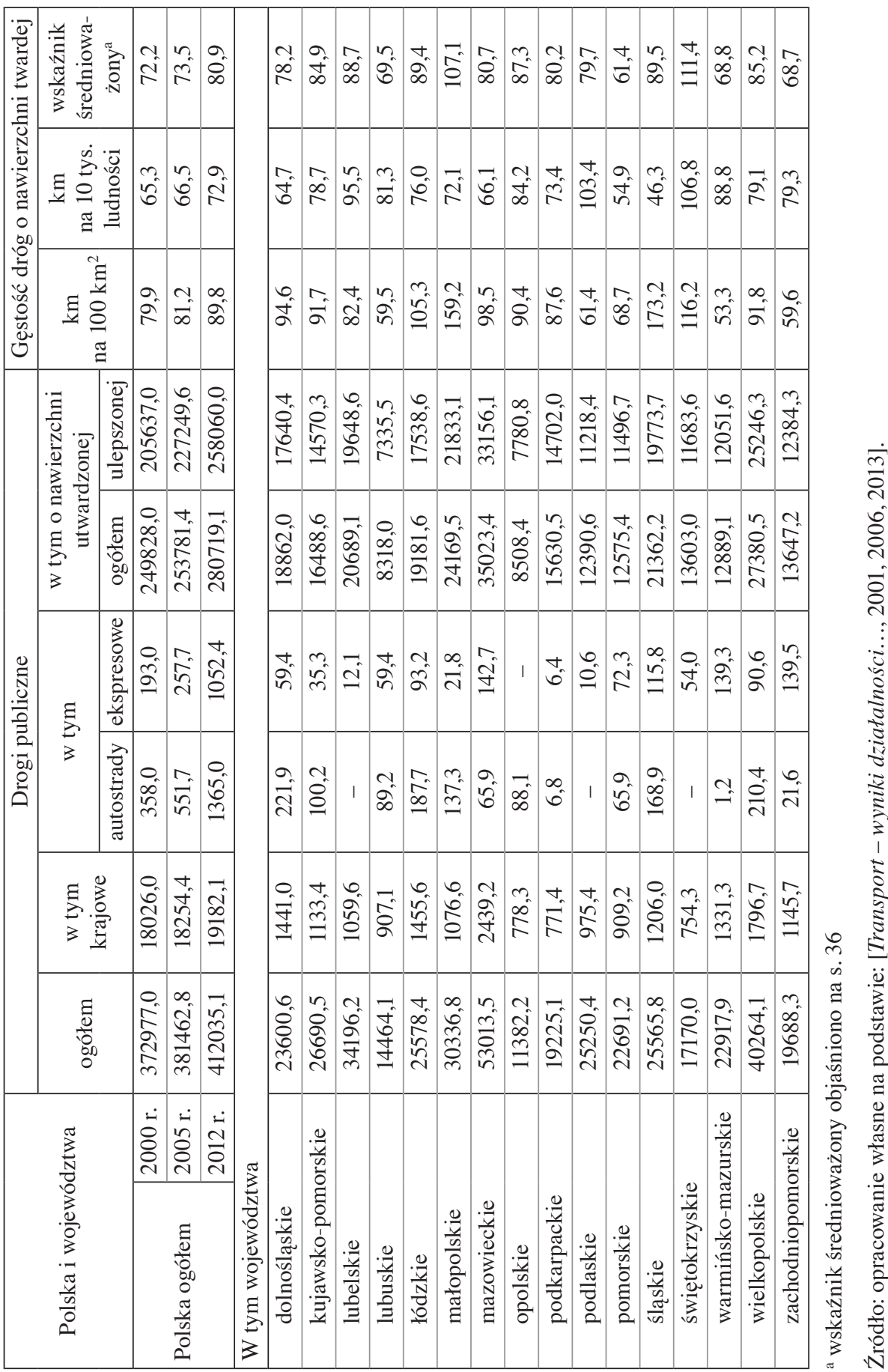


długości dróg w kraju jest nieznaczny (odpowiednio 4,6\% i 3,6\%). Na koniec 2012 r. na $100 \mathrm{~km}^{2}$ powierzchni oraz na 10 tys. ludności kraju przypadało odpowiednio 0,43 i 0,35 km długości autostrad. Dla 27 krajów UE średnia wartość tego wskaźnika była dużo wyższa i wynosiła odpowiednio 1,6 i 1,4 [Transport-wyniki działalności 2011, s. 263]. W 2012 r. trzy województwa (lubelskie, podlaskie i świętokrzyskie) nie miały w ogóle autostrad, zaś dróg ekspresowych nie miało województwo opolskie (tabela 1).

Jednym z podstawowych parametrów służących do zbadania użytkowania sieci drogowej jest wskaźnik średniodobowego natężenia ruchu środków transportu ${ }^{2}$. Średni dobowy ruch pojazdów na sieci dróg krajowych wyniósł w 2010 r. 9888 pojazdów/dobę i wzrósł o $41 \%$ od 2000 r. Najwyższe wskaźniki obciążenia dróg krajowych ruchem odnotowano w województwie śląskim (18 262 pojazdy), a następnie w małopolskim (12 953 pojazdy) i łódzkim (11 471 pojazdy), najmniej zaś obciążona była sieć drogowa w województwach warmińsko-mazurskim (5684 pojazdy), podlaskim (6702 pojazdy) i zachodniopomorskim (6892 pojazdy). W porównaniu z 2000 r., we wszystkich województwach wzrósł ruch środków transportu; najbardziej w województwach podlaskim (o 60,2\%) i dolnośląskim (o 54,2\%), najmniej zaś w łódzkim (o 26,7\%) i wielkopolskim (o 29,5\%) - rys. 1.

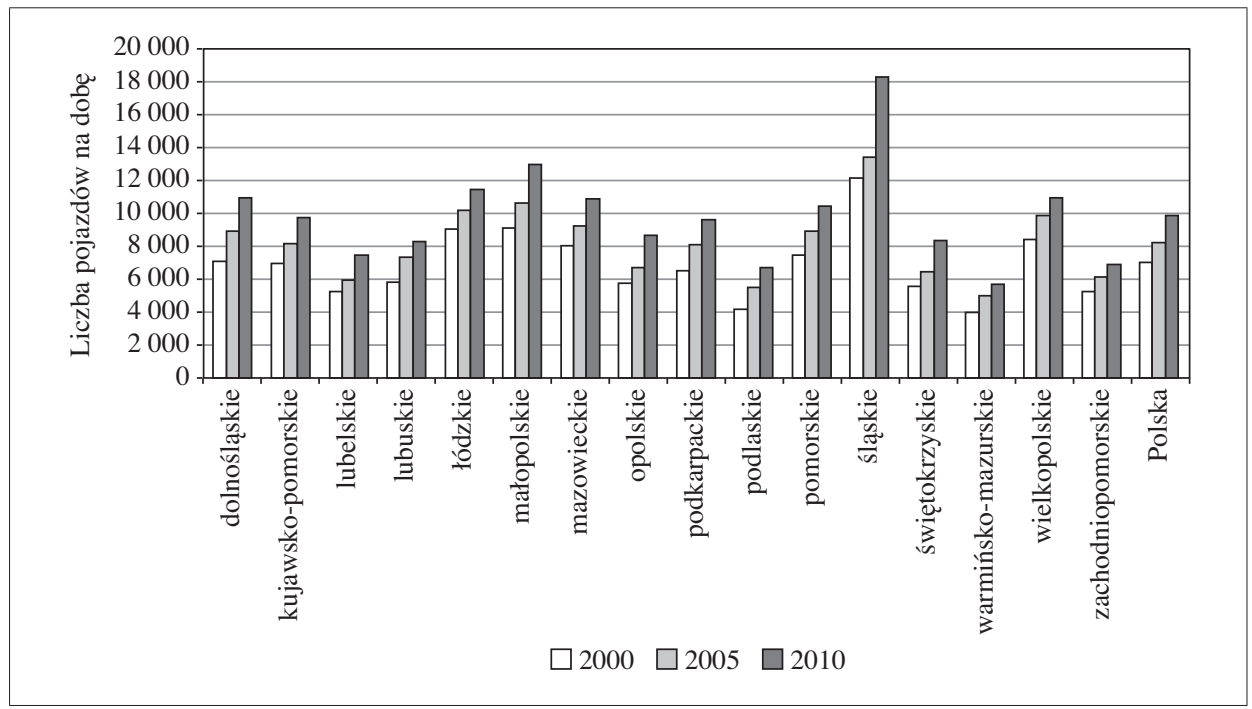

Rys. 1. Dobowe natężenie ruchu na sieci dróg krajowych w Polsce w latach 2000, 2005 i 2010 według województw

Źródło: opracowanie własne na podstawie: [Opoczyński 2000, 2005, 2010].

${ }^{2}$ Badania natężenia ruchu przeprowadzane są co 5 lat przez GDDKiA - ostatnio wykonano je w $2010 \mathrm{r}$. 
W Polsce ok. 38\% sieci drogowej jest w stanie technicznym złym lub niezadowalającym, wymaga więc przeprowadzenia różnego rodzaju remontów, w tym około 14\% (stan zły) wymaga natychmiastowych remontów. W latach 2000-2012 spadł odsetek dróg krajowych o złym stanie nawierzchni i przybyło odcinków dróg o stanie dobrym i zadowalającym ${ }^{3}$.

W poszczególnych województwach stan nawierzchni dróg jest zróżnicowany, co potwierdza wskaźnik natychmiastowych potrzeb remontowych, odzwierciedlający stosunek długości sieci w złym stanie do ogólnej długości sieci. Największy odsetek dróg krajowych w stanie dobrym i zadowalającym występował w województwach pomorskim i zachodniopomorskim, najmniejszy zaś w województwie kujawsko-pomorskim.

Tabela 2. Stan techniczny nawierzchni sieci dróg krajowych w województwach w Polsce w 2012 r. (w \%)

\begin{tabular}{|c|c|c|c|c|}
\hline \multicolumn{2}{|c|}{ Wyszczególnienie } & $\begin{array}{c}\text { Stan nawierzchni } \\
\text { dobry i zadowalający }\end{array}$ & $\begin{array}{l}\text { Stan nawierzchni } \\
\text { niezadowalający }\end{array}$ & Stan nawierzchni zły \\
\hline \multirow[t]{3}{*}{ Polska } & 2000 & 23,6 & 41,6 & 34,8 \\
\hline & 2005 & 48,9 & 26,2 & 24,9 \\
\hline & 2012 & 62,7 & 23,8 & 13,5 \\
\hline \multicolumn{5}{|c|}{ W tym województwa } \\
\hline \multicolumn{2}{|c|}{ dolnośląskie } & 53,0 & 29,3 & 17,7 \\
\hline \multicolumn{2}{|c|}{ kujawsko-pomorskie } & 52,1 & 30,3 & 16,1 \\
\hline \multicolumn{2}{|c|}{ lubelskie } & 65,6 & 17,4 & 16,9 \\
\hline \multicolumn{2}{|c|}{ lubuskie } & 61,8 & 27,4 & 10,8 \\
\hline \multicolumn{2}{|c|}{ łódzkie } & 66,0 & 21,9 & 12,2 \\
\hline \multicolumn{2}{|c|}{ małopolskie } & 57,5 & 27,9 & 14,6 \\
\hline \multicolumn{2}{|c|}{ mazowieckie } & 61,4 & 23,2 & 15,4 \\
\hline \multicolumn{2}{|c|}{ opolskie } & 62,1 & 27,8 & 10,1 \\
\hline \multicolumn{2}{|c|}{ podkarpackie } & 57,2 & 27,5 & 15,4 \\
\hline \multicolumn{2}{|c|}{ podlaskie } & 65,5 & 19,6 & 14,9 \\
\hline \multicolumn{2}{|c|}{ pomorskie } & 77,4 & 15,6 & 7,0 \\
\hline \multicolumn{2}{|c|}{ śląskie } & 58,5 & 31,4 & 10,0 \\
\hline \multicolumn{2}{|c|}{ świętokrzyskie } & 66,6 & 21,7 & 11,7 \\
\hline \multicolumn{2}{|c|}{ warmińsko-mazurskie } & 69,9 & 18,7 & 11,4 \\
\hline \multicolumn{2}{|c|}{ wielkopolskie } & 55,8 & 27,9 & 16,3 \\
\hline \multicolumn{2}{|c|}{ zachodniopomorskie } & 74,9 & 14,1 & 11,0 \\
\hline
\end{tabular}

Źródło: opracowanie własne na podstawie: [Raport o stanie technicznym, 2001, 2006, 2013].

${ }^{3}$ Drogi krajowe o złym stanie nawierzchni w 2000 r. - 5591 km, w 2012 r. - 2664 km, drogi krajowe w stanie dobrym i zadowalającym w 2000 r. - 10494 km, w 2012 r. - 17076 km [Raport o stanie technicznym...2001, 2013]. 
Najwięcej odcinków dróg w złym stanie technicznym, których nawierzchnie wymagają natychmiastowych remontów, było w województwie dolnośląskim (17,7\%), najmniej zaś w pomorskim (7,0\%) (tabela 2).

Pogarsza się infrastruktura drogowa, a równocześnie szybko wzrasta liczba samochodów. Liczba zarejestrowanych samochodów osobowych w 2012 r. wyniosła $18,7 \mathrm{mln}^{4}$. W Polsce w latach 2000-2012 odnotowano wzrost liczby samochodów o 87,6\%, zaś długość dróg utwardzonych zwiększyła się zaledwie o $12,4 \%$. Oznacza to, że przyrost sieci dróg nie nadąża za wzrostem liczby samochodów. Wskaźnik motoryzacji (liczba samochodów osobowych przypadająca na 1000 ludności) w 2012 r. wyniósł 486 (wobec 459 w 2000 r.). Najwyższy zanotowano w województwach: wielkopolskim (546), mazowieckim (536) i opolskim (531), z kolei najniższy w województwach podlaskim (421), podkarpackim (431) i warmińsko-mazurskim (434) - rys. 2.

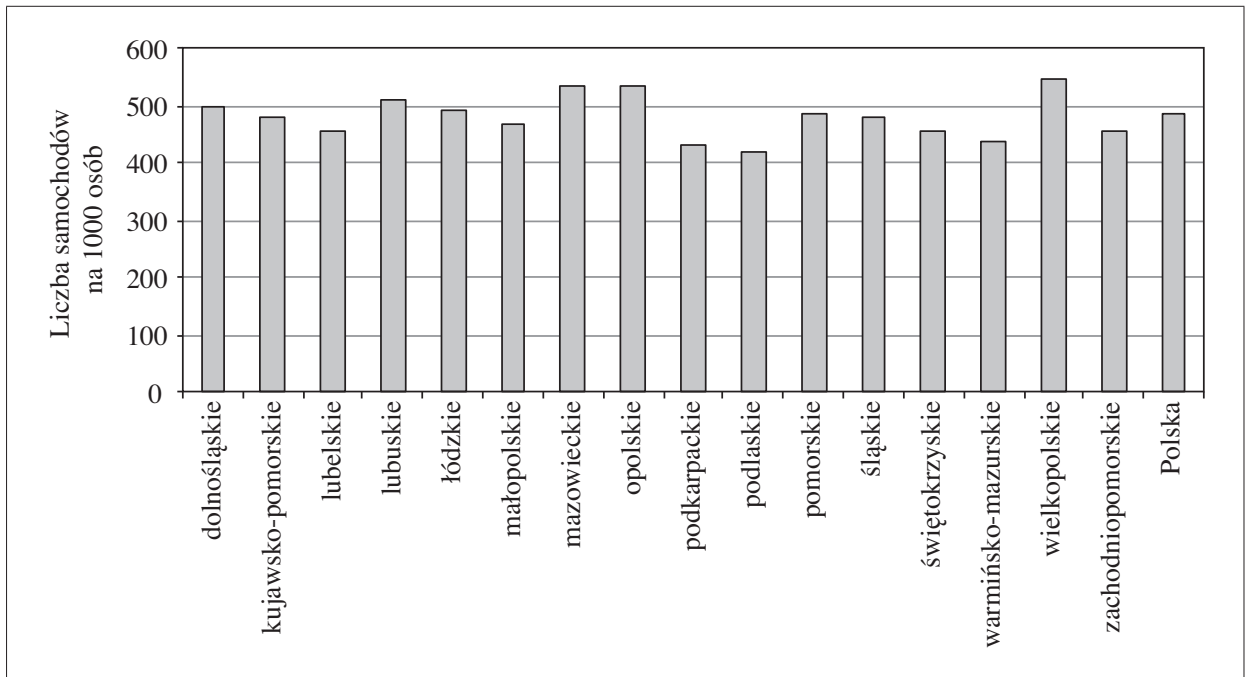

Rys. 2. Liczba samochodów osobowych na 1000 mieszkańców w województwach Polski w 2012 r.

Źródło: opracowanie własne na podstawie: [Bank Danych Lokalnych 2014].

Istotnym elementem systemu komunikacyjnego jest transport kolejowy. Sieć kolejową w Polsce, dobrze rozwiniętą pod względem ilościowym, charakteryzuje też wysoki stopień elektryfikacji oraz duży odsetek linii dwutorowych i wielo-

\footnotetext{
${ }^{4}$ Samochody osobowe w Polsce w 2000 r. - 9991,3; w 2005 r. - 12 339,4; w 2012 r. - 18 744,4. Samochody osobowe/1000 ludności w 2000 r. - 259, w 2005 r. - 323, w 2012 r. 486 [Bank Danych Lokalnych 2013].
} 


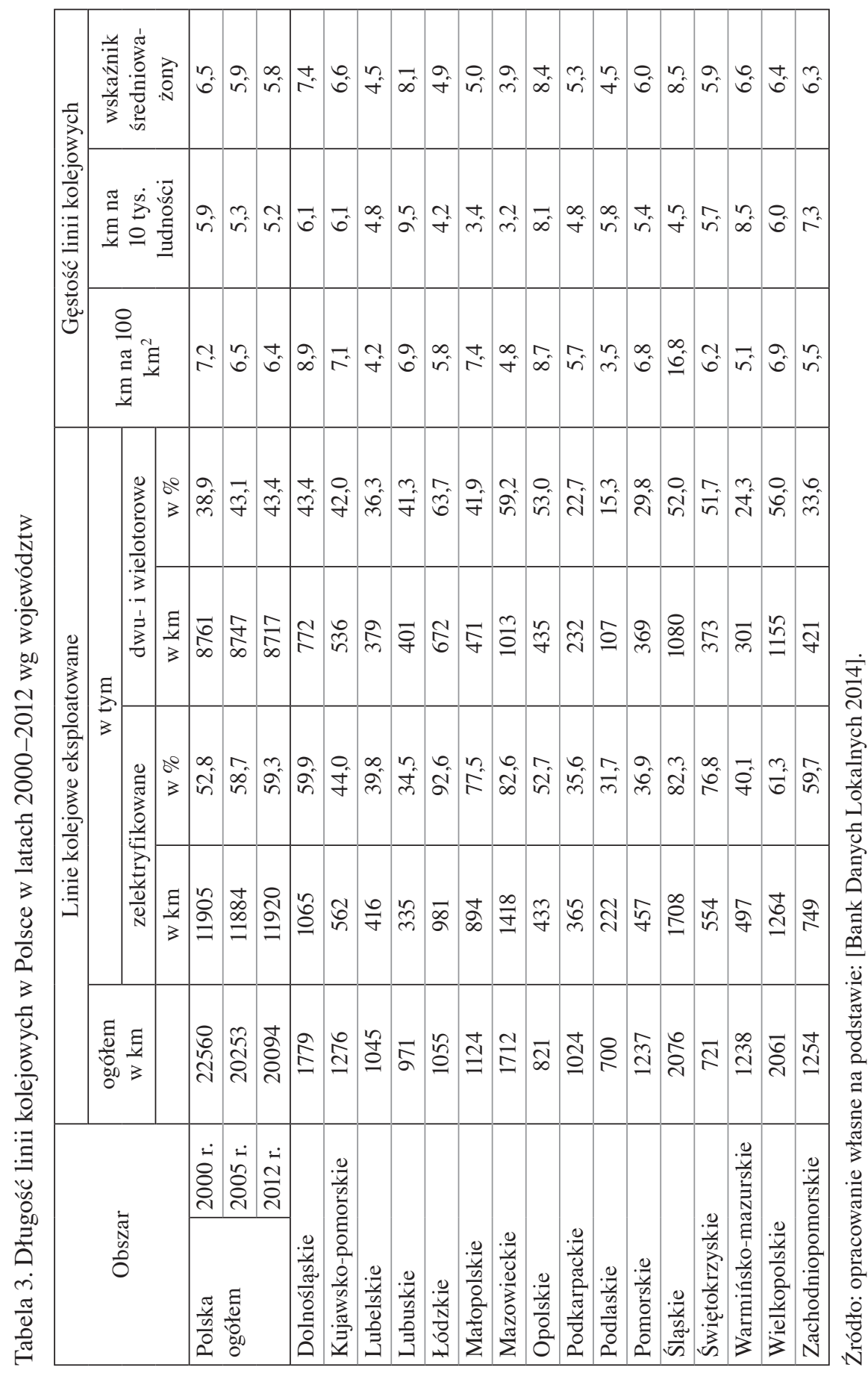


torowych $(43,4 \%)$ - tabela 4 . Polska sieć kolejowa posiada jednak gorsze cechy eksploatacyjne w porównaniu z siecią kolejową państw członkowskich Unii Europejskiej. W 2012 r. długość linii kolejowych eksploatowanych wynosiła $20094 \mathrm{~km}$, co daje gęstość linii kolejowych na poziomie $6,5 \mathrm{~km} / 100 \mathrm{~km}^{2}$. W porównaniu z 2000 r. długość tej sieci zmalała o ponad 12\% (tabela 3). Najwyższa gęstość linii kolejowych w 2012 r. kształtowała się na poziomie 16,8 dla województwa śląskiego, natomiast najniższa - w województwach: podlaskim $(3,5)$, lubelskim $(4,2)$ i mazowieckim $(4,8)$.

Sieć kolejowa w Polsce z uwagi na usytuowanie naszego kraju między Europą Zachodnią i Wschodnią oraz pomiędzy krajami skandynawskimi i krajami środkowo-wschodniej Europy, które nie mają dostępu do morza oraz Bałkanami, może być wykorzystywana dla połączeń tranzytowych, a nawet z regionami dalszymi, jak Chiny, Indie, Bliski i Daleki Wschód [Koncepcja przestrzennego... 2011].

W wyniku wieloletnich zaniedbań sieć kolejowa w Polsce wymaga wielu działań interwencyjnych, skierowanych przede wszystkim na remonty i naprawę elementów infrastruktury (m.in.: torów, obiektów inżynieryjnych, urządzeń energetyki). Duże znaczenie dla rozwoju infrastruktury transportowej ma też dostosowanie kolejowej sieci transportowej do wymogów Unii Europejskiej.

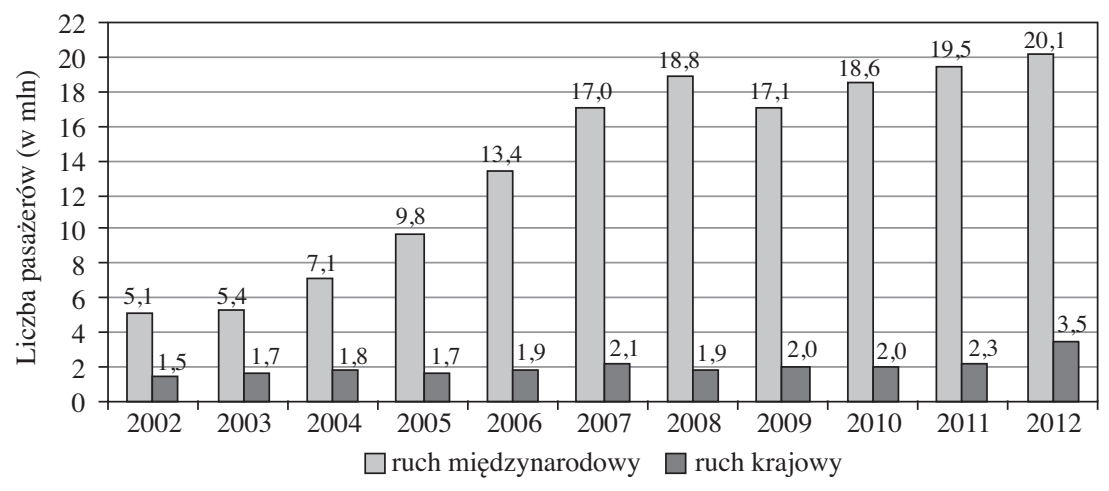

Objaśnienie: bank Danych Lokalnych zawiera dane dotyczące ruchu pasażerów w portach lotniczych w podziale na ruch krajowy i międzynarodowy od $2002 \mathrm{r}$.

Rys. 3. Ruch pasażerów w portach lotniczych w latach 2002-2012

Źródło: opracowanie własne na podstawie: [Musiał-Malagó 2013, s. 104; Bank Danych Lokalnych 2014].

Szczególną rolę we współczesnym transporcie odgrywa transport lotniczy. Na poprawę dostępności przestrzennej ma wpływ bliskość portu lotniczego. W Polsce niemal wszystkie duże ośrodki miejskie obsługiwane są przez transport 
lotniczy. Daje to możliwość rozwoju połączeń polskich miast głównie z miastami europejskimi. Po 2004 r. miała miejsce intensyfikacja i decentralizacja ruchu lotniczego. Od tego czasu znacznie wzrósł ruch pasażerów w polskich portach lotniczych. W 2012 r. odprawiono tam 23 677,4 tys. pasażerów, tj. prawie 3-krotnie więcej, niż w 2002 r. Większy wzrost odnotowano w komunikacji międzynarodowej niż w krajowej. Regularna komunikacja lotnicza utrzymywana jest z 91 miastami, w tym z 82 w sieci międzynarodowej [Bank Danych Lokalnych 2013].

Infrastruktura transportu lotniczego, w porównaniu z silnie zdekapitalizowaną infrastrukturą transportu drogowego i kolejowego, jest relatywnie nowoczesna i w znacznie większym stopniu zbliżona do standardów europejskich.

\section{Metodologia badania}

Wśród ekonomistów, planistów i geografów panuje duża różnorodność w klasyfikacji metod badania i pomiaru dostępności transportowej. Na podstawie przeglądu literatury przedmiotu można wyróżnić sześć metod analizy dostępności transportowej [Komornicki 2010, s. 36-37], tj.:

- dostępność mierzona wyposażeniem infrastrukturalnym - jest ona określana za pomocą wskaźników wyposażenia infrastrukturalnego obszaru (ilość i jakość infrastruktury),

- dostępność mierzona odległością - odległość fizyczna, fizyczna rzeczywista, czasowa, ekonomiczna do celu/celów zbioru podróży,

- dostępność mierzona izochronami - polega na wyznaczaniu stref o jednakowej odległości czasowej, mierzona jest przez oszacowanie zbioru celów podróży dostępnych w określonym czasie lub przy określonym koszcie czy wysiłku podróży,

- dostępność potencjalna - jest mierzona możliwością zajścia interakcji między źródłem podróży a zbiorem celów podróży (różnych wariantów dostępności mierzonej za pomocą wskaźników potencjału lub modeli grawitacji),

- dostępność mierzona w geografii czasu lub czasoprzestrzeni - może być mierzona przez szacowanie jednostkowych, specyficznych podróży między źródłem a celem,

- dostępność mierzona maksymalizacją użyteczności - jest mierzona zachowaniem użytkownika systemu transportowego.

Jedną z szeroko stosowanych metod ewaluacji polityki transportowej jest dostępność mierzona za pomocą wskaźników wyposażenia infrastrukturalnego, bowiem ten rodzaj dostępności można określić za pomocą wskaźników ilościowych i jakościowych infrastruktury [Koźlak 2012, s. 190]. 
Do oceny dostępności transportowej regionów autor zastosował metodę standaryzowanych sum z grupy taksonomicznych metod bezwzorcowych. Polega ona na budowie syntetycznego wskaźnika będącego sumą znormalizowanych wartości wskaźników cząstkowych. Badania oparto na podstawie danych statystycznych wg stanu na koniec 2012 r. Przeprowadzone badanie pozwala na opracowanie rankingu i typologię województw pod względem ich dostępności transportowej. Przyjęta metodologia badań zakłada w pierwszej kolejności wyznaczenie zmiennych diagnostycznych.

W analizie zróżnicowania dostępności przestrzennej duży wpływ na wyniki badań ma odpowiedni zestaw mierników. Cechy diagnostyczne zostały w tym badaniu dobrane na podstawie kryteriów merytorycznych i charakteryzują w możliwie pełny sposób jednostki badanego zbioru. Jednak dobór ten był zdeterminowany m.in. dostępnością danych statystycznych. Konstrukcja wskaźników syntetycznych opiera się na wskaźnikach cząstkowych przyporządkowanych do dwóch grup w transporcie osób, tj. obrazujących dostępność drogową i kolejową [Koźlak 2012, s. 214].

W celu doprowadzenia cech do porównywalności dokonano ich standaryzacji. Standaryzację cech przeprowadzono przy wykorzystaniu tzw. formuły zero-jedynkowej uwzględniającej średnią arytmetyczną i odchylenie standardowe zbioru wartości standaryzowanej cechy. W następnej kolejności skonstruowano wskaźniki syntetyczne, które uporządkowano monotonicznie, co umożliwiło klasyfikację badanych województw z punktu widzenia ich dostępności przestrzennej.

Do badania w zakresie infrastruktury transportu drogowego przyjęto następujący zestaw mierników:

$x_{1}$ - średnioważony wskaźnik nasycenia infrastrukturą drogową,

$x_{2}$ - odsetek dróg krajowych przypadających na województwo,

$x_{3}$ - odsetek autostrad i dróg ekspresowych przypadających na województwo,

$x_{4}$ - wskaźnik natychmiastowych potrzeb remontowych (odsetek dróg w stanie złym),

$x_{5}$ - czas dojazdu z miasta wojewódzkiego do Warszawy (min),

$x_{6}$ - czas dojazdu z miasta wojewódzkiego do pozostałych miast wojewódzkich (min),

$x_{7}$ - czas przejazdu z miasta na prawach powiatu do miasta wojewódzkiego (min),

$x_{8}$ - wskaźnik zmotoryzowania ludności.

Z kolei do badań z zakresu transportu kolejowego przyjęto następujące cechy diagnostyczne:

$x_{1}$ - średnioważony wskaźnik nasycenia infrastrukturą kolejową,

$x_{2}$ - udział województwa w długości dróg kolejowych,

$x_{3}$ - udział linii kolejowych dwutorowych i więcej, 
$x_{4}$ - czas dojazdu do Warszawy (min),

$x_{5}$ - czas dojazdu do pozostałych miast wojewódzkich (najkrótszy czas przejazdu, przy założeniu jednej przesiadki).

Wartości prezentowanych mierników zestawiono w tabelach 4 i 5.

Tabela 4. Wartości cech określających poziom dostępności drogowej województw w 2012 r.

\begin{tabular}{|l|c|c|c|c|c|c|c|c|}
\hline \multirow{2}{*}{\multicolumn{1}{|c|}{ Województwo }} & \multicolumn{7}{c|}{ Mierniki $^{\mathrm{a}}$} \\
\cline { 2 - 9 } & $X_{1}$ & $X_{2}$ & $X_{3}$ & $X_{4}$ & $X_{5}$ & $X_{6}$ & $X_{7}$ & $X_{8}$ \\
\hline Dolnośląskie & 78,2 & 7,5 & 11,6 & 17,7 & 257,0 & 3292,0 & 225,0 & 495,3 \\
\hline Kujawsko-pomorskie & 84,9 & 5,9 & 5,6 & 16,1 & 206,0 & 3548,0 & 200,0 & 477,6 \\
\hline Lubelskie & 88,7 & 5,5 & 0,5 & 16,9 & 138,0 & 4071,0 & 409,0 & 456,9 \\
\hline Lubuskie & 69,5 & 4,7 & 6,1 & 10,8 & 236,0 & 3520,0 & 92,0 & 506,6 \\
\hline Łódzkie & 89,4 & 7,6 & 11,6 & 12,2 & 89,0 & 2756,0 & 107,0 & 489,7 \\
\hline Małopolskie & 107,1 & 5,6 & 6,6 & 14,6 & 231,0 & 3468,0 & 152,0 & 466,4 \\
\hline Mazowieckie & 80,7 & 12,7 & 8,6 & 15,4 & 0,0 & 3043,0 & 197,0 & 535,5 \\
\hline Opolskie & 87,3 & 4,1 & 3,6 & 10,1 & 238,0 & 3318,0 & $0,0 \mathrm{~b}$ & 531,1 \\
\hline Podkarpackie & 80,2 & 4,0 & 0,5 & 15,4 & 269,0 & 4237,0 & 205,0 & 431,0 \\
\hline Podlaskie & 79,7 & 5,1 & 0,4 & 14,9 & 144,0 & 4406,0 & 172,0 & 421,2 \\
\hline Pomorskie & 61,4 & 4,7 & 5,7 & 7,0 & 242,0 & 4194,0 & 165,0 & 483,5 \\
\hline Śląskie & 89,5 & 6,3 & 11,8 & 10,0 & 200,0 & 3131,0 & 456,0 & 478,1 \\
\hline Świętokrzyskie & 111,4 & 3,9 & 2,2 & 11,7 & 145,0 & 3343,0 & 0,0 & 454,2 \\
\hline Warmińsko-mazurskie & 68,8 & 6,9 & 5,8 & 12,8 & 159,0 & 4213,0 & 77,0 & 433,5 \\
\hline Wielkopolskie & 85,2 & 9,4 & 12,5 & 16,3 & 164,0 & 3135,0 & 378,0 & 546,2 \\
\hline Zachodniopomorskie & 68,7 & 6,0 & 6,7 & 11,0 & 326,0 & 4720,0 & 649,0 & 456,0 \\
\hline
\end{tabular}

a mierniki objaśniono na s. $44,{ }^{b}$ stolica województwa jest równocześnie jedynym miastem na prawach powiatu w danym województwie.

Źródło: opracowanie własne na podstawie: [Transport. Wyniki działalności w 2000, 2005 i 2012 r., www.stat.gov.pl, Bank Danych Lokalnych 2014].

Tabela 5. Wartości cech określających poziom dostępności kolejowej województw w 2012 r.

\begin{tabular}{|l|c|c|c|c|c|}
\hline \multirow{2}{*}{\multicolumn{1}{c|}{ Województwo }} & \multicolumn{5}{|c|}{ Mierniki $^{\mathrm{a}}$} \\
\cline { 2 - 6 } & $X_{1}$ & $X_{2}$ & $X_{3}$ & $X_{4}$ & $X_{5}$ \\
\hline Dolnośląskie & 7,4 & 8,8 & 43,4 & 325,0 & 4400,0 \\
\hline Kujawsko-pomorskie & 6,6 & 6,3 & 42,0 & 199,0 & 4442,0 \\
\hline Lubelskie & 4,5 & 5,2 & 36,3 & 140,0 & 4989,0 \\
\hline Lubuskie & 8,1 & 4,8 & 41,3 & 317,0 & 5602,0 \\
\hline Łódzkie & 4,9 & 5,2 & 63,7 & 117,0 & 4218,0 \\
\hline
\end{tabular}


cd. tabeli 5

\begin{tabular}{|l|c|c|c|c|c|}
\hline \multirow{2}{*}{ Województwo } & \multicolumn{5}{|c|}{ Mierniki $^{\mathrm{a}}$} \\
\cline { 2 - 6 } & $X_{1}$ & $X_{2}$ & $X_{3}$ & $X_{4}$ & $X_{5}$ \\
\hline Małopolskie & 5,0 & 5,6 & 41,9 & 181,0 & 4410,0 \\
\hline Mazowieckie & 3,9 & 8,5 & 59,2 & $0,0^{\mathrm{b}}$ & 3371,0 \\
\hline Opolskie & 8,4 & 4,1 & 53,0 & 309,0 & 4857,0 \\
\hline Podkarpackie & 5,3 & 5,1 & 22,7 & 365,0 & 7290,0 \\
\hline Podlaskie & 4,5 & 3,5 & 15,3 & 161,0 & 5878,0 \\
\hline Pomorskie & 6,0 & 6,1 & 29,8 & 305,0 & 5648,0 \\
\hline Śląskie & 8,7 & 10,3 & 52,0 & 173,0 & 4304,0 \\
\hline Świętokrzyskie & 5,9 & 3,6 & 51,7 & 206,0 & 5038,0 \\
\hline Warmińsko-mazurskie & 6,6 & 6,1 & 24,3 & 199,0 & 5761,0 \\
\hline Wielkopolskie & 6,4 & 10,2 & 56,0 & 157,0 & 3758,0 \\
\hline Zachodniopomorskie & 6,3 & 6,2 & 33,6 & 319,0 & 6117,0 \\
\hline
\end{tabular}

a mierniki objaśniono na s. $44,{ }^{b}$ czas przejazdu do Warszawy wynosi 0 .

Źródło: opracowanie własne na podstawie: [Transport... 2001, 2006 i 2013, Bank Danych Lokalnych 2014 oraz http://rozklad.sitkol.pl/bin/query.exe/pn? (dostęp: 2013)].

W dalszej kolejności wyliczono wskaźniki syntetyczne dostępności transportowej dla transportu drogowego i kolejowego. Wartości wskaźnika syntetycznego uporządkowano od wartości największej do najmniejszej (najwyższa pozycja oznacza najwyższą wartość i najlepszą dostępność transportową). Wyniki porządkowania zawiera tabela 6.

Na bazie tych uporządkowanych wartości przeprowadzono podział województw na cztery grupy typologiczne, I - o bardzo dobrej dostępności transportowej, II o dobrej dostępności, III - o średniej dostępności i IV - o niskiej dostępności transportowej. Granice przedziałów wyznaczono na podstawie obliczonych wartości średniej arytmetycznej i odchylenia standardowego miernika syntetycznego.

Zdecydowanie najlepszą dostępność drogową ma województwo mazowieckie, następnie łódzkie i wielkopolskie, zaliczane też do I klasy (rys. 4, tabela 6). W najtrudniejszej sytuacji pod względem dostępności drogowej są zaś województwa we wschodniej Polsce oraz województwo zachodniopomorskie. Województwa te charakteryzują się słabym wyposażeniem w infrastrukturę transportu i ze względu na peryferyjne położenie w skali kraju, czas dojazdu stamtąd do pozostałych miast wojewódzkich jest stosunkowo długi. Najniższe miejsca w tym rankingu odnotowały województwa zachodniopomorskie, podkarpackie, podlaskie i lubelskie. 
Tabela 6. Klasy dostępności transportowej województw w Polsce w 2012 r.

\begin{tabular}{|c|c|c|c|c|c|}
\hline \multicolumn{3}{|c|}{ Dostępność drogowa } & \multicolumn{3}{|c|}{ Dostępność kolejowa } \\
\hline Województwo & $\begin{array}{c}\text { wskaźnik } \\
\text { syntetyczny }\end{array}$ & $\begin{array}{c}\text { klasy } \\
\text { w rankingu }\end{array}$ & Województwo & $\begin{array}{c}\text { wskaźnik } \\
\text { syntetyczny }\end{array}$ & $\begin{array}{c}\text { klasy } \\
\text { w rankingu }\end{array}$ \\
\hline Mazowieckie & 0,987 & \multirow{3}{*}{ I } & Śląskie & 1,143 & \multirow{3}{*}{ I } \\
\hline Łódzkie & 0,838 & & Wielkopolskie & 1,017 & \\
\hline Wielkopolskie & 0,535 & & Mazowieckie & 0,957 & \\
\hline Opolskie & 0,308 & \multirow{6}{*}{ II } & Łódzkie & 0,428 & \multirow{4}{*}{ II } \\
\hline Świętokrzyskie & 0,306 & & Dolnośląskie & 0,346 & \\
\hline Śląskie & 0,299 & & Kujawsko-pomorskie & 0,229 & \\
\hline Małopolskie & 0,133 & & Opolskie & 0,119 & \\
\hline Dolnośląskie & 0,027 & & Małopolskie & $-0,027$ & \multirow{6}{*}{ III } \\
\hline Lubuskie & 0,026 & & Świętokrzyskie & $-0,125$ & \\
\hline $\begin{array}{l}\text { Kujawsko- } \\
\text {-pomorskie }\end{array}$ & $-0,135$ & \multirow{3}{*}{ III } & Lubuskie & $-0,197$ & \\
\hline Pomorskie & $-0,199$ & & Lubelskie & $-0,253$ & \\
\hline $\begin{array}{l}\text { Warmińsko- } \\
\text {-mazurskie }\end{array}$ & $-0,220$ & & $\begin{array}{l}\text { Warmińsko- } \\
\text {-mazurskie }\end{array}$ & $-0,319$ & \\
\hline Lubelskie & $-0,547$ & \multirow{4}{*}{ IV } & Pomorskie & $-0,519$ & \\
\hline Podlaskie & $-0,607$ & & Zachodniopomorskie & $-0,543$ & \multirow{3}{*}{ IV } \\
\hline Podkarpackie & $-0,838$ & & Podlaskie & $-0,952$ & \\
\hline Zachodniopomorskie & $-0,912$ & & Podkarpackie & $-1,304$ & \\
\hline
\end{tabular}

Źródło: opracowanie własne na podstawie danych w tabelach 4 i 5.

Wysoką dostępność kolejową mają województwa śląskie, wielkopolskie i mazowieckie, a najniższą województwa Polski północnej (zachodniopomorskie) i wschodniej (podlaskie i podkarpackie) - rys. 5, tabela 6).

Wynikiem słabo rozwiniętego systemu transportowego jest przede wszystkim niska dostępność przestrzenna wielu regionów. W Polsce bezpośrednie połączenia między ważnymi ośrodkami sieci osadniczej są słabo rozwinięte, a ponadto ich jakość jest niezadowalająca. Ograniczona dostępność komunikacyjna do niektórych obszarów kraju, szczególnie do miast wojewódzkich, pełniących ważne funkcje społeczno-gospodarcze oraz administracyjne, stanowi jedną z największych barier rozwojowych. Niska dostępność transportowa zmniejsza możliwości rozprzestrzeniania się procesów rozwojowych z ośrodków będących „biegunami wzrostu" do obszarów słabiej rozwijających się. Powoduje to trudności w niwelowaniu procesów marginalizacji i peryferyzacji obszarów kraju [Koncepcja przestrzennego..., 2011]. 
Klasy dostępności:

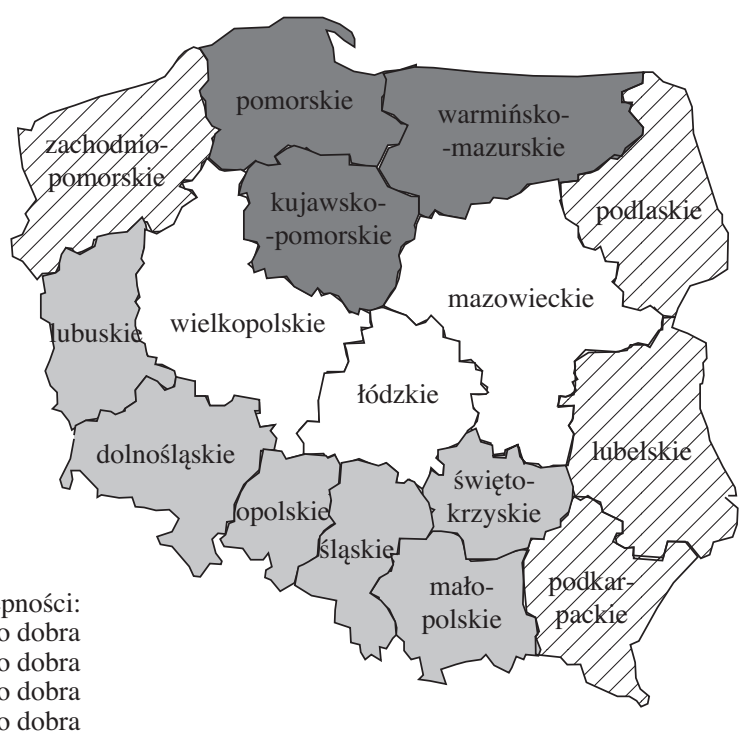

Rys. 4. Dostępność drogowa województw w 2012 r.

Źródło: opracowanie własne.

Klasy dostępności:

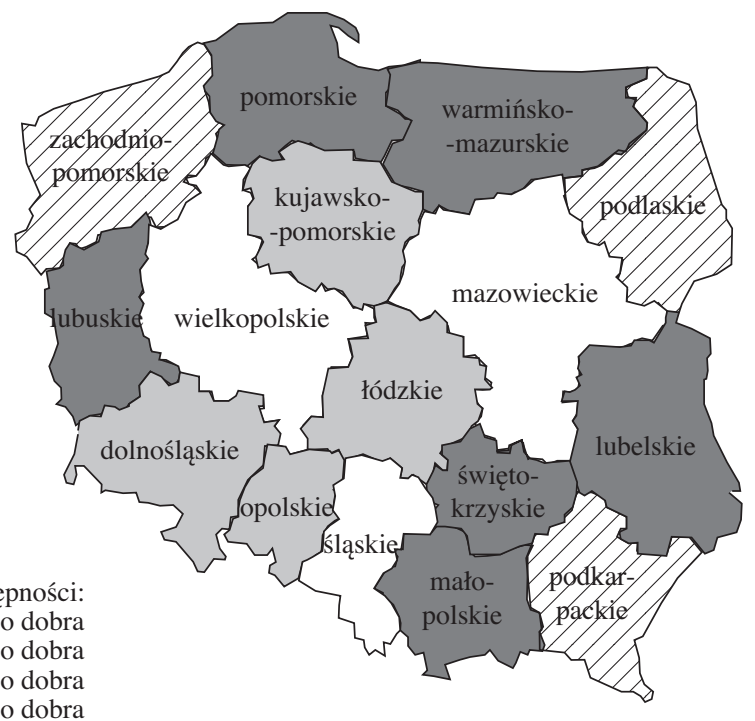

Rys. 5. Dostępność kolejowa województw w 2012 r.

Źródło: opracowanie własne. 


\section{Podsumowanie}

Pomimo wzmożonego wysiłku inwestycyjnego w Polsce w dalszym ciągu brakuje spójnego i sprawnie funkcjonującego systemu transportowego zintegrowanego z systemem europejskim. Bez efektywnego i sprawnego transportu nie będzie możliwe przyspieszenie wzrostu gospodarczego kraju. Ze względu na cele rozwojowe Polski konieczne jest, aby transport stanowił istotny element przyczyniający się do wszechstronnego rozwoju kraju poprzez stworzenie funkcjonalnie zintegrowanej infrastruktury, wdrożenie nowych technologii transportowych i zapewnienie społeczeństwu wysokiej jakości usług na konkurencyjnym rynku transportowym.

Zaniedbania w infrastrukturze transportowej zarówno drogowej, jak i kolejowej spowodowały, że znaczna część obszarów naszego kraju charakteryzuje się niską dostępnością transportową. Obecnie największą dostępnością transportową drogową charakteryzują się województwa mazowieckie, wielkopolskie i łódzkie. Biorąc pod uwagę transport kolejowy najlepiej dostępne są województwa mazowieckie, wielkopolskie i śląskie. Z kolei obszarami o niedostatecznej dostępności transportowej zarówno drogowej, jak i kolejowej są województwa ściany wschodniej i województwo zachodniopomorskie.

Infrastruktura transportu jest jednym z ważniejszych czynników stymulujących rozwój gospodarczy kraju. Zajmuje ona istotne miejsce wśród priorytetów, które odnoszą się do konkurencyjności i innowacyjności gospodarek, poprawy stanu infrastruktury technicznej oraz budowy spójności terytorialnych, jakie zostały wyznaczone w dokumentach strategicznych, m.in. w Strategii rozwoju kraju na lata 2010-2020.

\section{Literatura}

Bank Danych Lokalnych [2013], www.stat.gov.pl (dostęp: 5.12.2013).

Komornicki T. et al. [2010], Dostępność przestrzenna jako przesłanka kształtowania polskiej polityki transportowej, Biuletyn KPZK PAN, z. 241, Warszawa.

Koncepcja przestrzennego zagospodarowania kraju 2030 [2010], Ministerstwo Rozwoju Regionalnego, Warszawa.

Koźlak A. [2012], Nowoczesny system transportowy jako czynnik rozwoju regionów w Polsce, Wydawnictwo Uniwersytetu Gdańskiego, Gdańsk.

Musiał-Malagó M. [2007], Infrastruktura transportowa w Polsce, „Zeszyty Naukowe Akademii Ekonomicznej w Krakowie", nr 746.

Musiał-Malagó M. [2013a], Stan i kierunki rozwoju infrastruktury transportowej w Polsce, ,Zeszyty Naukowe Akademii Ekonomicznej w Krakowie”, nr 914.

Musiał-Malagó [2013b], The Diversity of Transport Accesibility in Polish Regions, artykuł przedstawiony na międzynarodowej konferencji w Wenecji, „Trasporti, organizzazione 
spaziale e sviluppo economico sostenibile", http://www.sietitalia.org/siet2013/venezia. htm.

Opoczyński K. [2000], Generalny pomiar ruchu 2000. Synteza wyników, http://www. gddkia.gov.pl (dostęp: 4.05.2013).

Opoczyński K. [2005], Generalny pomiar ruchu 2005. Synteza wyników, http://www. gddkia.gov.pl (dostęp: 4.05.2013).

Opoczyński K. [2010], Synteza wyników GPR 2010, http://www.gddkia.gov.pl (dostęp: 4.05.2013).

Raport o stanie technicznym nawierzchni asfaltowych i betonowych sieci dróg krajowych z lat 2000, 2005, 2012 [2001, 2006, 2012], Generalna Dyrekcja Dróg Krajowych i Autostrad, Warszawa.

Transport - wyniki działalności w 2000 r. [2001], GUS, Warszawa.

Transport-wyniki działalności w 2005 r. [2006], GUS, Warszawa.

Transport - wyniki działalności w 2012 r. [2013], GUS, Warszawa.

\section{The Diversity of Transport Accessibility of Polish Voivodeships}

The current level of transport infrastructure and its technical condition is a barrier to Poland's further economic growth and modernisation, and also to the country's full integration with the EU where transport policy is concerned. The underdevelopment of Poland's transport infrastructure reduces the spatial accessibility of many urban centres and regions on the regional, domestic and European scale.

My research on transport accessibility is based on taxonomic methods. The aim of this study was to identify the diversity of transport accessibility in Poland by voivodeship, using synthetic measures to rank each province. The study was based on statistical data for the end of 2012.

Keywords: transport infrastructure, spatial accessibility, transport accessibility, road network, rail network. 